\title{
RELEVANSI PEMIKIRAN PROFESOR IMAM SUPRAYOGO TERHADAP PERKEMBANGAN EKONOMI SYARIAH DI INDONESIA
}

\author{
Yayan Nasikin \\ Pascasarjana UIN Maulana Malik Ibrahim Malang \\ yayannasikin@gmail.com \\ Eka Putri Innayah \\ Pascasarjana UIN Maulana Malik Ibrahim Malang \\ Innayahekaputri77@gmail.com \\ Shimah Fauziah Yeubun \\ Pascasarjana UIN Maulana Malik Ibrahim Malang \\ zhimafauzia@gmail.com \\ Helmi Syaifuddin \\ Pascasarjana UIN Maulana Malik Ibrahim Malang \\ Helmi.syaifuddin@uin-malang.ac.id
}

\begin{abstract}
ABSTRAK
Profesor Imam Suprayogo memiliki sebuah konsep pemikiran mengenai integrasi Islam dan sains dalam bidang pendidikan yang memiliki tujuan untuk melahirkan generasi yang memiliki kecerdasan baik kecerdasan emosional, intelektual maupun spiritual. Konsep pemikiran tersebut lebih dikenal dengan sebutan Tarbiyah Ulul Al-albab. Penelitian ini merupakan penelitian kualitatif deskriptif. Penelitian ini memiliki tujuan untuk menganalisis relevansi pemikiran Imam Suprayogo dalam mendukung perkembangan ekonomi syariah di Indonesia. Hasil penelitian ini menunjukan bahwa pemikiran Imam suprayogo memiliki relevenasi terhadap perkembangan ekonomi syariah di Indonesia, dimana konsep integrasi antara Islam dan sains yang diusung beliau pada dasarnya menekankan terciptanya sumber daya manusia yang ideal menurut Islam.
\end{abstract}

Kata Kunci : Sumber daya Manusia, Tarbiyah Ulul Al-albab, ekonomi syariah.

\section{PENDAHULUAN}

Pendidikan di Indonesia memiliki makna suatu usaha secara sadar dan terencana dalam mewujudkan kondisi serta suasana belajar serta proses pembelajaran yang bertujuan agar para peserta didik dapat dengan aktif meningkatkan perkembangan potensi dalam dirinya untuk memiliki kekuatan baik secara spiritual keagamaan, kepribadian, kecerdasan intelektual, akhlakul kharimah, serta keterampilan mumpuni yang diperlukan untuk kepentingan 
dirinya sendiri, masyarakat umum, bangsa dan negara (UUD RI Nomor 20 Tahun 2003 Tentang Sistem Pendidikan Nasional Dengan Rahmat Tuhan Yang Maha Esa Presiden Republik Indonesia, n.d.)

Pendidikan yang merupakan usaha untuk membina dan mengembangkan pribadi manusia baik secara aspek rohaniah maupun jasmani haruslah dilakukan secara bertahap. Namun, suatu proses yang diinginkan dalam usaha kependidikan adalah dengan alur yang terarah dan memiliki tujuan, yaitu memberi arah terhadap anak didik (manusia) kepada titik paling optimal atas kemampuan dalam dirinya. Sedangkan tujuan yang dimaksud yakni tercapainya pembentukan kepribadian yang secara utuh sebagai manusia sosial dan individu serta hamba Tuhan yang tunduk dan mengabdikan diri kepada-Nya (Anwar Arifin; Indonesia. Direktorat Jenderal Pembinaan Kelembagaan Agama Islam; Indonesia, 2003. Hal 12).

Di Indonesia secara umum mengenal dua model sistem pendidikan, yaitu model pendidikan nasional dan model pendidikan lokal. Berdasarkan hal tersebut, dalam potret umumnya pendidikan terbagi menjadi dua yakni pendidikan formal yang diselenggarakan oleh negara dan pendidikan non formal yang diselenggerakan oleh pesantren. Selama ini, secara umum banyak anggapan bahwa telah terjadi dikotomi antara ilmu agama dan ilmu umum yang dimana hal tersebut salah satunya disebabkan oleh faktor internal kelembagaan pendidikan Islam yang kurang mampu melakukan upaya pembenahan dan pembaruan.

Islam yang disebut bersifat universal pada faktanya, kajiannya masih sangat terbatas dan juga kurang memiliki daya tarik, bahkan berakibat mengalami ketertinggalan. Berkaitan dengan struktur keilmuannya, yang awalnya bersifat dikotomi seharusnya diubah menjadi bangunan ilmu yang bersifat integratif. AlQur'an dan Al-Hadits yang semula dijadikan obyek kajian kemudian direposisi menjadi sumber kajian untuk semua bidang kelimuan. Langkah ini didasarai oleh pertimbangan pemikiran bahwa ilmu pengetahuan sesungguhnya tidaklah layak dipilah-pilah menjadi ilmu agama dan ilmu umum (Fatkurrohman, 2008. Hal 103104).

Berdasarkan anggapan dikotomi keilmuan tersebut, maka Imam Suprayogo menggagas sebuah konsep pemikiran mengenai pendidikan yakni pendidikan yang tujuannya untuk melahirkan generasi yang memiliki kecerdasan baik kecerdasan emosional, intelektual maupun spiritual. Konsep pemikiran tersebut lebih dikenal dengan sebutan Tarbiyah Ulul Al-albab. Tarbiyah Ulul Al$a l b a b$ ini kemudian diterapkan pada sistem pendidikan perguruan tinggi tepatnya di Universitas Islam Negeri Maulana Malik Ibrahim Malang (UIN Malang).

Prof. Imam Suprayogo kemudian melakukan pengintegrasian antara ilmu Islam dan Sains yang merupakan penyempurnaan atau penyatuan ilmu-ilmu yang selama ini dianggap terpisah sehingga akan menghasilkan satu pola pemahaman menyeluruh tentang konsep ilmu pengetahuan. Pengintegrasian ilmu dalam lembaga pendidikan Islam sudah sejak lama digaungkan, hal tersebut didasari atas kesadaran serta kecemasan akan peran dari sebuah lembaga pendidikan dalam 
menangani dan menjawab berbagai permasalahan kemanusiaan yang amat kompleks. Integrasi keilmuan pada bidang pendidikan khususnya pendidikan Islam adalah sesuatu yang diharapkan. Sebab, seperti telah diketahui, sejak awal kemerdekaan, keberadaan lembaga pendidikan Islam selalu menempati posisi pinggiran (Darwis \& Rantika, 2018. Hal 2).

Tujuan dalam penulisan artikel ini adalah untuk menganalisis relevansi antara konsep pemikiran Imam Suprayogo dengan perkembangan Ekonomi Islam di era modern saat ini.

Manfaat penulisan artikel yakni pertama secara teoritis bagi perkembangan ilmu pengetahuan, hasil penelitia ini diharapkan dapat memperkaya khasanah dalam keilmuan terkait Ekonomi Islam serta menambah wawasan dan pengetahuan bagi pembaca mengenai penelitian relevansi antara pemikiran Prof. Imam Suprayogo terhadap Ekonomi Islam.

\section{KAJIAN LITERATUR}

\section{Ekonomi Islam}

\section{Pengertian Ekonomi Islam}

Ekonomi Islam adalah sebuah sistem ilmu pengetahuan fokus pembahasannya yaitu masalah perekonomian yang mana nilai-nilai Islam dijadikan sebagai landasan dan dasar dalam setiap aktifitasnya.

Menurut Abdul Manan ilmu Ekonomi Islam adalah ilmu pengetahuan sosial yang mempelajari permasalahan ekonomi dalam masyarakat yang diterapkan berdasarkan atas nilai-nilai Islam. (Manan, 1980. Hal 13)

Sedangkan menurut M. Umer Chapra, beliau berpendapat bahwa Ekonomi Islam adalah sebuah pengetahuan yang membantu dalam upaya realisasi kebahagiaan manusia yang dilakukan melalui sumber daya terbatas yang berada dalam koridor dengan acuan terdapat pada ajaran Islam tanpa memberi kebebasan individu dan tanpa ketidakseimbangan lingkungan. (Nasution Mustofa Edwin, 2006. Hal 16)

Jadi, dapat diambil kesimpulan bahwa Ekonomi Islam merupakan suatu bidang ilmu yang mempelajari dan membahas kemudian menganalisis permasalahan terkait ekonomi dalam masyarakat dan akhirnya mencari penyelesaian permasalahan-permasalahan ekonomi tersebut dengan mengacu kepada nilai-nilai Islam.

2. Dasar Hukum Ekonomi Islam

Setiap ilmu tentunya memiliki dasar hukum untuk dapat dinyatakan secara legal sebagai sebuah bagian dari konsep pengetahuan. Begitu pula dengan Ekonomi Syari'ah atau Ekonomi Islam.

Aktivitas ekonomi tentunya sangat sering melakukan berbagai transaksi dengan berbagai bentuk perjanjian yang disepakati. Dalam Ekonomi Islam, prinsip syari'ah sebuah perjanjian diwajibkan dibuat secara 
tertulis atau biasa yang disebut dengan akad. Berikut beberapa dasar hukum Ekonomi Islam, yaitu :

a. Al-Qur'an

Al-Qur'an memberikan ketentuan dan ketetapan hukum muamalat yang mana sebagian besar dalam bentuk kaidah umum. Dalam Al-Qur'an terdapat beberapa ayat mengenai dasar hukum Ekonomi Islam, salah satunya pada Q.S. Al-Baqarah ayat 188 terdapat larangan makan harta dengan cara yang tidak sah, misalnya suap dengan bunyi ayatnya sebagai berikut,

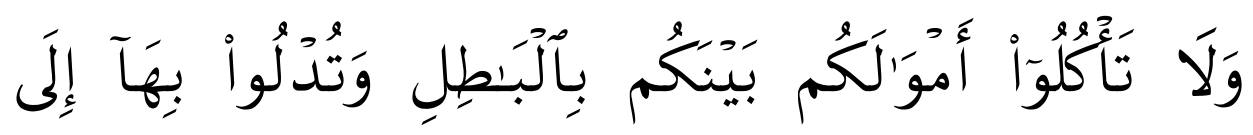

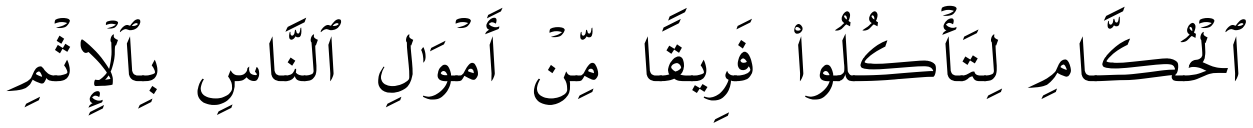

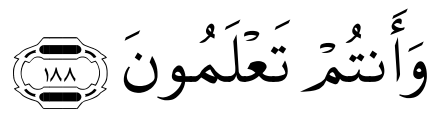

Artinya : "Dan janganlah sebahagian kamu memakan harta sebahagian yang lain di antara kamu dengan jalan yang bathil dan (janganlah) kamu membawa (urusan) harta itu kepada hakim, supaya kamu dapat memakan sebahagian daripada harta benda orang lain itu dengan (jalan berbuat) dosa, Padahal kamu mengetahui”. (Q.S. Al-Baqarah Ayat 188)

Dalam Surah lain, seperti Q.S. An-Nisa ayat 29, yakni ketentuan terkait perdagangan yang dilakukan denga dasar suka rela merupakan salah satu bentuk Muamalat yang halal, ayatnya sebagai berikut,
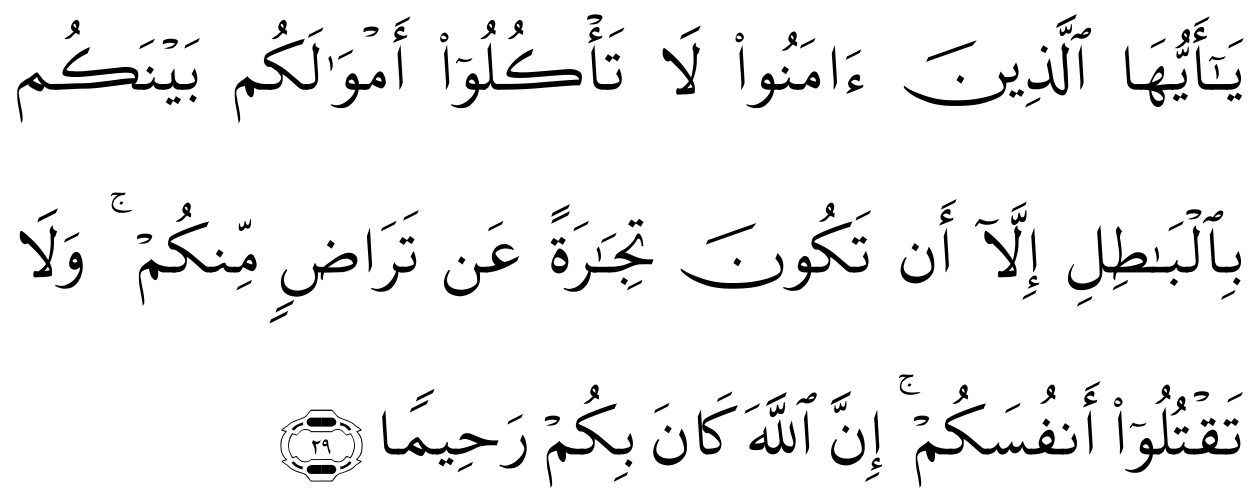

Artinya: "Hai orang-orang yang beriman, janganlah kamu saling memakan harta sesamamu dengan jalan yang batil, kecuali dengan jalan perniagaan yang Berlaku dengan suka sama- 
b. Al-Hadits

suka di antara kamu. dan janganlah kamu membunuh dirimu. Sesungguhnya Allah adalah Maha Penyayang kepadamu”. (Q.S. An-Nisa Ayat 29)

Hadits yang berkaitan dengan Ekonomi Islam yakni yang diriwayatkan oleh Ibnu Majah, Ad-Daruquthni, dan lain-lain dari Sa'id Al-khudri ra. Bahwa Rasulullah SAW bersabda :

"Janganlah merugikan diri sendiri dan janganlah merugikan orang lain”. (Ibnu Majah, Hal 743)

\section{Biografi Prof. Imam Suprayogo}

Imam Suprayogo merupakan anak laki-laki dari pasangan $\mathrm{KH}$ Hasan Muchroji (alm) dan Hj. Mariyah. Dalam istilah pada kamus bahasa Jawa Suprayogo memiliki arti imam yang baik. (Fitriani, 2005 Hal 69). Dengan pemberian nama tersebut, tentunya ada makna yang terkandung di dalamnya yang menjadi harapan kelak di masa depan Imam Suprayogo mampu menjadi pemimpin yang baik bagi keluarga, masyarakat, bangsa dan agamanya.

Imam Suprayogo lahir di Desa Gemoharjo Watulimo yaitu sebuah desa di wilayah Trenggalek. Gemaharjo adalah sebuah desa di pegunungan yang terletak $32 \mathrm{~km}$ di sebelah Selatan kota Trenggalek dengan kira-kira7 km dari pantai selatan pulau Jawa. Imam hidup sebagai anak pedesaaan yang melakukan aktifitas seperti masyarakat di desa pada umumnya. Namun, Imam telah dikenalkan dengan niai-nilai religious oleh ayahandanya yang juga merupakan tokoh agama di desa tempatnya tinggal. (Fatkurrohman, 2008. Hal 23).

Lingkungan keluarga yang sarat dengan warna keagamaan dan kehidupan desanya yang keras dan sedari kecil sudah dituntut mengenai pemenuhan tanggung jawab itulah kiranya yang telah membentuk kepribadian Imam sehingga saat ia tumbuh menjadi seorang pemimpin pengalaman itu pula yang ikut menyertai sikap dan jalan fikirnya seperti sekarang. (Nasution Mustofa Edwin, 2006 Hal 36). Adapun riwayat pendidikan Imam Suprayogo sebagai berikut :

1. Pendidikan Dasar di Sekolah Rakyat (SR) pada tahun 1958-1965

2. SMPN di Kota Kawedanan Kampak

3. SMAN Trenggalek

4. IAIN Fakultas Tarbiyah

Sebelum hijrah ke UIN Malang, Imam Suproyogo bekerja di Universitas Muhammadiyah selama 20 tahun, mulai dari menjadi tata usaha, wakil dekan, dekan, dan sebagai pembantu rektor I selama 13 tahun. Di samping itu, beliau pernah ditunjuk menjadi pengurus Majelis PKU Kabupaten Malang, kemudian sebagai Ketua Majelis Pendidikan Dasar dan menengah Muhammadiyah Kabupaten Malang hingga 10 tahun, dan bersamaan dengan itu juga pernah ditunjuk menjadi anggota Majelis Pendidikan Tinggi Pimpinan Pusat Muhammadiyah (Fatkurrohman, 2008. Hal 24). 
Sewaktu memimpin UIN, Imam Suprayogo dinobatkan sebagai pemimpin pendidikan yang sangat cemerlang oleh MURI Indonesia (2006) dalam memimpin dunia pendidikan Islam (Arifan, n.d. Hal 2). Kegemarannya menulis artikel setiap ba da solat shubuh, membuat beliau memegang Rekor MURI untuk konsistensi menulis setiap hari di blog "3 tahun tanpa jeda". Hebatnya lagi, sebagai orang yang lama berkarir di Perguruan tinggi milik Muhammadiyah, beliau dipercaya menjadi Musytasar PCNU kota Malang untuk periode 2011-2016 (Suprayogo, 2014).

\section{Pemikiran Prof. Imam Suprayogo}

Imam Suprayogo mengindetifikasi bahwa pendidikan Islam mengalami ketertinggalan yang mana masih terjebak pada pemikiran-pemikiran klasik. Para pemikir Muslim masih segan dalam melakukan reformulasi dan modernisasi pemikiran. Dari problema pendidikan Islam tersebut, Imam Suprayogo menawarkan sebuah konsep pendidikan dengan paradigma Al-Qur'an dengan semboyan Tarbiyah Ulul Albab.

Tarbiyah Ulul Albab wujud nyatanya adalah penggabungan antara pesantren dengan perguruan tinggi. Sebagaimana yang telah lazim diketahui bahwa keberadaan pesantren sebagai pusat pendidikan agama Islam yang berdiri untuk melahirkan manusia yang mengedepankan dzikir. Begitupun perguruan tinggi yang berdiri untuk menghasilkan manusia dengan mengedepankan berpikir, yang kemudian dari keduanya terlahirlah amal shaleh (Jannah, 2015. Hal 10). Iman, ilmu dan amal menjadi sasaran utama untuk dikembangkan secara seimbang.

Dalam konsep pengintegrasian ilmu dan agama, Imam Suprayogo mengambil metafora pohon ilmu yakni sebuah pohon yang kokoh, bercabang, rindang, berdaun subur, dan berbuah lebat karena ditopang oleh akar yang kuat. Batang merupakan kelompok tumbuhan yang memiliki batang yang kuat, kokoh dan berkayu. Batang yang kokoh ialah gambaran ilmu-ilmu yang terkait dan sumber utamanya dari AL-Qur'an dan Al-Hadits Nabi yakni lebih spesifik ialah Studi Al-Qur'an, Studi Al-Hadits, pemikiran Islam dan Sirah Nabawiyah. Secara khusus ilmu-ilmu tersebut akan dikaji kemudian dipahami dengan lebih baik oleh mereka yang memang sudah memiliki kemahiran dalam bahasa Arab, logika, ilmu alam dan ilmu sosial.

Sementara akar yang kokoh menancap kuat ke bumi yang digunakan untuk penggambaran kemampuan dalam berbahasa asing (Arab dan Inggris), logika dan filsafat, ilmu-ilmu alam dan ilmu-ilmu sosial. Bahasa asing, khususnya Arab dan Inggris, haruslah dikuasai oleh individu mahasiswa. Penggunaan bahasa Arab digunakan sebagai piranti dalam mendalami pemahaman ilmu-ilmu yang bersumber dari Al-Qur'an dan Hadits serta kitab-kitab lain yang berbahasa Arab. Kemudian, penggunaan bahasa Inggris dipandang penting sebagai bahasa internasional yaitu bahasa ilmu pengetahuan dan tekhnologi juga sebagai bahasa pergaulan di taraf internasional. 
Pohon ilmu diharapkan mampu membuahkan orang-orang yang beriman, berakhlak mulia, berilmu, dan beramal șhaleh. Di mana pun dan kapan pun bahwa penyandang derajat setinggi itu tidak akan membebani orang lain, tetapi justru sebaliknya, selalu memberi manfaat bagi kehidupan. Berbekalkan kekayaan ilmunya, ketajaman pandangan mata dan telinganya, serta kelembutan hatinya, mereka akan berjuang di jalan Allah SWT dengan sebenar-benarnya perjuangan. Orang seperti ini kehadirannya, sebagai buah pohon ilmu, akan selalu membawa manfaat bagi siapapun.

\section{METODE PENELITIAN}

\section{Jenis Penelitian}

Jenis penelitian ini merupakan penilitian kualitatif deskriptif. kualitatif deskriptif adalah metode deskriptif merupakan suatu metode dalam meneliti status sekelompok manusia, suatu objek, suatu set kondisi, suatu sistem pemikiran ataupun suatu kelas peristiwa pada masa sekarang. Tujuan dari penelitian deskriptif ini adalah untuk membuat deskripsi, gambaran, atau lukisan secara sistematis, faktual dan akurat mengenai fakta-fakta, sifat-sifat serta hubungan antar fenomena yang diselidiki (Nazir, 1988 Hal. 63).

\section{Sumber data}

Data yang digunakan dalam penelitian ini adalah data sekunder. Data sekunder merupakan data yang didapat dari literatur-literatur kepustakaan seperti buku-buku artikel, surat kabar, internet serta sumber lain yang berkaitan dengan materi yang menjadi pembahasan bagi penulis.

\section{Analisis data}

Penelitian ini melewati beberapa langkah-angkah antara lain : Pertama, penulis menetapkan tokoh pemikiran yang akan dikaji, dalam hal ini pemikiran profesor Imam Suprayogo terkait intgerasi Islam dan sains. Kedua penulis mengumpulkan dan menyeleksi data memlalui data skunder berupa literatur jurnal, penelitian, buku dan internet terkait konsep pemikiran tokoh. Ketiga penulis mengkaji pemikiran tokoh dan mengelaborasikannya denga fenomena perkembangan ekonomi syariah. Kelima penulis melakukan analisis kritis terhadap relevansi pemikiran tokoh dalam mendukung perkembangan ekonomi syariah.

\section{HASIL DAN PEMBAHASAN}

Perkembangan ekonomi Islam di Indonesia dewasa ini telah menunjukan kemajuan yang cukup pesat dan patut untuk diapresiasi. Hal ini dapat terlihat dari banyaknya pemikiran ekonomi syariah yang terus dikembangkan oleh para ahli ekonomi dan sarjanawan. Perkembangan tersebut tidak hanya dijumpai pada tataran wacana yang hanya bersifat teoritik-normatif, namun sudah sampai pada 
tataran yang lebih praktis-aplikatif, terlihat dengan hadirnya lembaga keuangan yang berbasis syariah seperti perbankan dan lembaga keuangan syariah lainnya serta terus mengalami pertumbuhan yang cukup signifikan. Berdasarkan data publikasi Otoritas Jasa Keuangan Pada tahun 2018 sektor perbankan syariah berjumlah 14 buah dengan total aset sebesar 304,292 miliar rupiah. Adapun pada sektor investasi, Reksadana syariah hingga November 2018 berjumlah sebesar 220 atau sekitar 10,61\% dari total reksadana. Efek syariah juga terus mengalami pertumbuhan dimana hingga November 2018 berjumlah 407 efek syariah. Begitu pula dengan jumlah sukuk syariah mencapai 108 sukuk syariah. Disisi lain perkembangan Lembaga keuangan mikro syariah pada akhir November 2018 diperkirakan berjumlah 4500 Baitul Maal Wat Tamwil. Perkembangan ekonomi syariah juga terlihat dari hadirnya Bank Wakaf Mikro sebagai penyedia layanan akses pembiayaan bagi masyarakat kecil dengan memanfaatkan dana wakaf (Keuangan, 2018).

Perkembangan ekonomi syariah pada satu sisi menciptakan kegembiraan atas optimisme masa depan ekonomi syariah sebagai sistem ekonomi alternatif, namun di sisi lain menghadirkan tantangan baru yaitu peningkatan kualitas. Peningkatan kualitas dapat diartikan sebagai peningkatan pelayanan dan produk yang bermuara pada sumber daya manusia. Dalam menjawab tantangan tersebut profesor Imam Suprayogo menawarkan sebuah konsep yang relevan terhadap peningkatan kualitas Sumber Daya Manusia (SDM) dalam mendukung perkembangan ekonomi syariah. Adapun konsep dari Imam Suprayogo ini dikenal dengan Tarbiyah ulul'albab atau konsep pada dunia pendidikan dengan berparadigma Al- Qur'an.

Tarbiyah ulul'albab adalah konsep yang digagas oleh profesor Imam Suprayogo yang hakikatnya memiliki tujuan utama yaitu mengintegrasikan Islam dan sains melalui pendidikan (Darwis \& Rantika, 2018. Hal 5). Sadar akan fenomena kualitas pendidikan yang semakin hari belum menunjukan kemajuan. Bahkan cenderung merosot diharapkan konsep ini dapat menjadi ikhtiar atau upaya perbaikan kualitas pendidikan yang berdampak pula pada penentuan outuput atau sumber daya manusia yang dihasilkan, dimana sumber daya manusia tersebut merupakan generasi-generasi yang diharapkan menjadi sumber daya manusia (SDM) yang ideal dalam segala aspek kehidupan termasuk perkembangan ekonomi syariah.

Insan ulul albab secara realistis dapat dibentuk melalui proses pendidikan yang ditawarkan oleh profesor Imam Suprayogo. Proses pendidikan tersebut ialah proses pendidikan yang mampu menciptakan iklim pendidikan yang dapat memungkinkan tumbuh dan berkembangnya karakter dzikr, fikr, dan amal shaleh (Malang, 2009 Hal 6). Bentuk rillnya adalah sarana pendidikan berupa lembaga yang terdiri atas penggabungan pesantren (ma'had) dan perguruan tinggi. Hal ini dikarenakan pesantren telah lama berkiprah dalam membentuk manusia - manusia yang mengedepankan dzikr, sedangkan perguruan tinggi ialah menghasilkan 
manusia yang matang dalam mengutamakan fikr, dan atas bersinerginya dasar kekuatan tersebut akan menghasilkan manusia yang berakhlak mulia serta memiliki kecenderungan untuk beramal shaleh.

Insan ulul albab akan selalu menjalankan kegiatan dan pelayanan yang terbaik serta penuh tanggung jawab kepada sesama, "khairunnas anfa'uhum linnash". Dalam dunia pekerjaan konsep insan ulul albab sudah pasti sangat berkaitan erat dengan sumber daya manusia yang secara menyeluruh tidak hanya cerdas dan terampil melainkan juga sangat dibutuhkan sifat-sifat dasar yang harus dimiliki tiap individunya. Diantara sifat-sifat tersebut ialah jujur, amanah, fathanah dan profesional (Rofiq, 2011. Hal 10). Jujur ialah sifat dasar untuk mengukur tingkat kekuatan karakter seseorang dalam sebuah perusahaan atau lembaga diseluruh bidang khususnya ekonomi. Kejujuran karyawan tentunya akan sangat mendukung perkembangan perusahaan di setiap divisi sekalipun banyak hal yang dianggap mampu menjadi godaan. Selanjutnya ialah sifat amanah. Amanah yang dimaksud ialah dapat dipercaya dan selalu menyampaikan segala sesuatunya dengan apa adanya (Akip, 2019. Hal 11). Sifat amanah dalam dunia ekonomi dapat diimplementasikan contohnya pada saat penyampaian produkproduk di perbankan syari'ah kepada masyarakat, dengan kata lain harus ada transparasi pada saat penyampaian sistematika pembiayaan atau akad yang akan digunakan oleh nasabah. Sifat berikutnya yaitu fathanah dan professional. Dalam Islam, kata fathanah dapat diartikan cerdas (Djuwarijah, 2008 Hal 19). Cerdas di sini diartikan secara luas yakni paham dalam menyeimbangkan perihal ilmu dunia guna mendukung bekal menuju dunia akhirat. Dalam ekonomi Islam, tentunya kecerdesan intelektual seseorang sangat dibutuhkan berkaitan dengan kemampuan atau skill tiap individu karyawan perusahaan. Kecerdasan tersebut juga akan sangat mempengaruhi tingkat profesionalitas para karyawan saat bekerja.

Dengan demikian Pengembangan sumber daya manusia berkaitan erat dengan kuantitas dan kualitas pengetahuan yang dimiliki, lembaga pendidikan ideal lah yang akan menghasilkan kualitas pengetahuan oleh karena itu konsep tarbiyah ulul albab dengan pendekatakan dzikr, fikr dan amal shaleh akan menghasilkan sumber daya manusia yang ideal serta memposisikan kualitas secara otomatis sesuai dengan tuntutan zaman. Konsep imam suprayogo pada dunia pendidikan inilah yang dinilai relevan dan mampu menjawab persoalan kendala pada perkembangan ekonomi syariah di Indonesia. Berdasarkan penjelasan diatas Tarbiyah ulul albab diharapkan mampu menghasilkan manusiamanusia yang ideal secara intelektual, emosional, dan spiritual.

\section{KESIMPULAN DAN SARAN}

\section{Kesimpulan}

Berdasarkan pemaparan diatas untuk itu peneliti mengambil kesimpulan bahwasanya Konsep pemikiran profesor Imam Suprayogo memiliki pengaruh yang relevan dalam mendukung perkembangan ekonomi syariah, 
penganggabungan antara lembaga pendidikan tinggi dan pesantren adalah terobosan dalam dunia pendidikan yang menekankan terciptanya karakter sumber daya manusia yang seimbang antara kecerdasan intelektual, kecerdasan emosional serta kecerdasan spiritual.

\section{Saran}

Berdasarkan pembahasan pada artikel ini maka, peneliti memiliki beberapa saran diantaranya sangat diharapkan lembaga-lembaga pendidikan yang ada di Indonesia mengaplikasikan konsep tarbiyah ulul albab yang di cetus dari hasil pemikiran prof Imam Suprayogo hal ini dikarenakan tarbiyah ulul albab akan menghasilkan generasi pembangun bangsa serta sumber daya manusia yang ideal, berkopeten, memiliki semangat juang dan mampu bertahan sesuai tuntutan perkembangan zaman agar senantiasa dapat mendukung perkembangan ekonomi syariah di Indonesia. Selanjutnya sangat diharapkan peneliti selanjutnya untuk lebih mengembangkan penelitian ini dengan subjek yang lebih relevan mengenai pemikiran prof Imam Suprayogo terhadap perkembangan ekonomi syariah.

\section{DAFTAR PUSTAKA}

Akip, M. (2019). Sumber Daya Manusia Yang Berkualitas Dalam Al-Quran. AlGhiroh, XVII(5), 55.

Anwar Arifin; Indonesia. Direktorat Jenderal Pembinaan Kelembagaan Agama Islam; Indonesia. (2003). Memahami Paradigma Baru Pendidikan Nasional dalam Undang-Undang Sisdiknas. Jakarta: Departemen Agama RI, Direktorat Jenderal Kelembagaan Agama Islam.

Arifan, F. A. (n.d.). Pemikiran Imam Suprayogo Dalam Pendidikan Islam.

Darwis, M., \& Rantika, M. (2018). Konsep Integrasi Keilmuan dalam Perspektif Pemikiran Imam Suprayogo. Fitra, 4(1), 1-11.

Djuwarijah, D. (2008). Peningkatan Kualitas Sumber Daya Manusia Melalui Pendidikan Islam. El-Tarbawi, 1(1), 13-26. https://doi.org/10.20885/tarbawi.vol1.iss1.art2

Fatkurrohman, D. (2008). Pemikiran dan aksi Imam Suprayogo dalam membangun kerjasama kelembagaan. http://etheses.uin-malang.ac.id/4820/

Fitriani, I. (2005). Kepemimpinan Imam Suprayogo dalam Perubahan dan Pengembangan Perguruan Tinggi (Study kasus UIN Malang).

Ibrahim, U. M. M. (n.d.). UNDANG-UNDANG REPUBLIK INDONESIA NOMOR 20 TAHUN 2003 TENTANG SISTEM PENDIDIKAN NASIONAL DENGAN RAHMAT TUHAN YANG MAHA ESA PRESIDEN REPUBLIK INDONESIA. 
Jannah, M. (2015). PENAFSIRAN ULUL AL-BAB DALAM TAFSIR AL-MISBAH. Universitas Islam Negeri Sunan Kali Jaga, Yogyakarta.

Keuangan, O. J. (2018). Siaran Pers: Sektor Jasa Keuangan pada Tahun 2018 Tumbuh Stabil dengan Kinerja Intermediasi yang Baik. https://www.ojk.go.id/id/berita-dan-kegiatan/siaran-pers/Pages/Siaran-PersSektor-Jasa-Keuangan-pada-Tahun-2018-Tumbuh-Stabil-dengan-KinerjaIntermediasi-yang-Baik.aspx

Malang, K. P. U. I. N. M. M. I. (2009). Tarbiyah ulî al-albâb: dzikr, fikr, dan amal shaleh.

Manan, M. A. (1980). Teori dan Pratik Ekonomi Islam. PT. Dana Bhakti Wakaf.

Nasution Mustofa Edwin, D. (2006). Pengenalan Ekslusif Ekonomi Islam. Kencana.

Nazir. (1988). Contoh Metode Penelitian. Ghalia Indonesia.

Rofiq, A. (2011). Sumber daya manusia berkualitas perspektif Nabi Syu'aib dalam al-Qur'an. 1999.

Suprayogo, I. (2014). Sekedar Melihat Foto Saya Bersama Kyai, Ibu Menangis. UIN Maulana Malik Ibrahim Malang. https://uinmalang.ac.id/r/140201/sekedar-melihat-foto-saya-bersama-kyai-ibumenangis.html 